\section{Factors associated with post-operative complications in oral carcinoma: prospective study}

\author{
Paulo Victor Sola Gimenes ${ }^{1}$, Daniel Abreu Rocha1, \\ Marco Aurélio Vamondes Kulcsar², Claudio Roberto Cernea ${ }^{1}$, Leandro Luongo Matos*
}

\begin{abstract}
Introduction: Patients who require surgery to treat head and neck cancer are at higher risk of perioperative complications and this scenario is not different for patients with malignant tumors of the oral cavity. Thus, the objective of the present study was to identify preoperative prognostic factors related to postoperative complications in the surgical treatment of oral cancer. Methods: Prospective study with 43 consecutive squamous cell carcinomas of the oral cavity submitted to surgical treatment with curative intent. Results: Seventeen patients presented postoperative complications until the thirtieth day of follow-up, of which $17.6 \%$ required surgical reoperation. The most common complications were suture dehiscence and surgical site infections. Alcohol abuse $(p=0.004)$, pT4a tumors $(p=0.044)$, tumors with thickness greater than $10 \mathrm{~mm}(p=0.002)$, patients with mGPS score 1 and $2(p=0.027)$ and flap reconstruction ( $p<0.001$ ) were associated with higher rates of postoperative complications. To the multivariate analysis, patients with tumor thickness greater than $10 \mathrm{~mm}(\mathrm{HR}=11,240,95 \%$ $\mathrm{Cl}:$ 1,052-120,059, $\mathrm{p}=0.045$ - logistic regression) and reconstructed with myocutaneous flap (HR=18,415, 95\% Cl: 1,849-183,359, $\mathrm{p}=0.013$ - logistic regression) had a higher risk of developing postoperative complications. Conclusion: Tumor thickness greater than $10 \mathrm{~mm}$ or use of myocutaneous flaps in the reconstruction were the predictors of risk of postoperative complications in patients with squamous cell carcinoma of the oral cavity.
\end{abstract}

Keywords: mouth neoplasms; postoperative complications; prognosis.

\section{Introduction}

Oral cavity cancer has the resection of the primary tumor associated with selective or therapeutic neck dissection as main treatment modality. The ablations of the primary lesions range from simple partial resections to combined procedures, such as mandibulectomies requiring the need for microsurgical reconstruction with free flaps or pedicled flap rotation.

Patients who require surgery to treat head and neck cancer are at a higher risk of perioperative complications and this scenario is no different for patients with malignant tumors of the oral cavity. Avoiding complications in the postoperative period is a challenge that starts with the identification of patients at higher risk of developing these complications ${ }^{1,2}$.

Many variables are implicated as prognostic factors for complications after surgery, including nutritional status, age, characteristics of the neoplasia and 
presence of comorbidities. Thus, the objective of this study was to identify preoperative prognostic factors related to postoperative complications in the surgical treatment of oral cancer ${ }^{1,2}$.

\section{Methods}

This is a prospective study, approved by the Research Ethics Committee (protocol 228/14), including 43 consecutive patients with squamous cell carcinoma of the oral cavity submitted to surgical treatment for curative purposes from August 2016 to April 2017. Those patients who underwent salvage surgeries or those with tumors of the lips were excluded.

The data collected were age, gender, primary site, degree of differentiation, alcoholism, smoking, clinical and pathological stage (TNM), tumor thickness, perineural and angiolymphatic invasion, resection margins, extracapsular spread, radiotherapy or adjuvant chemotherapy, body mass index (BMI), patient status by the KPS and ECOG scales, albumin and C-reactive protein (CRP) closer to the day of surgery for stratification of the Glasgow Modified Prognostic Score (mGPS), plus the need and type of the flap used in the reconstruction, and the presence of postoperative complications up to the thirtieth day.

The final pathological stage of all patients was reviewed according to the guidelines of the $8^{\text {th }}$ edition of the Cancer Staging Manual of the American Joint Committee on Cancer $^{3}$.

GPS is a prognostic score created in 2008 by the University of Glasgow by McMillan et al. ${ }^{4}$ to evaluate the repercussion of systemic inflammatory status in these patients. It evaluates the patient's CRP and albumin levels and graduates them according to these values: 0 points - CRP $\leq 10 \mathrm{mg} / \mathrm{L}$ and albumin $\geq 35 \mathrm{~g} / \mathrm{L}$; 1 point - CRP $\geq 10 \mathrm{mg} / \mathrm{L}$ or albumin $<35 \mathrm{~g} / \mathrm{L} ; 2$ points - CRP $>10 \mathrm{mg} / \mathrm{L}$ and albumin $<35 \mathrm{~g} / \mathrm{L}$. Since the finding of hypoalbuminemia without increase of CRP is rare and that hypoalbuminemia alone does not alter survival, the score was modified and mGPS was created ${ }^{5}$, which is quite similar to the previous one, and it changes only the graduated group with 1 point: 0 points - CRP $\leq 10 \mathrm{mg} / \mathrm{L}$ and albumin $\geq 35 \mathrm{~g} / \mathrm{L} ; 1$ point - CRP $\geq 10 \mathrm{mg} / \mathrm{L} ; 2$ points - CRP $>10 \mathrm{mg} / \mathrm{L}$ and albumin $<35 \mathrm{~g} / \mathrm{L} 4,5$.

Karnofsky performance scale is a classification developed by David A. Karnofsky in his 1948 article on the use of nitrogen mustard in the palliative treatment of carcinomas. This graduated scale of 0-100 points evaluates the patient's ability in developing activities through 11 different measures: 0 points (death); 10 points (dying, death process in rapid progression); 20 points (very weak, hospitalization required); 30 points (very incapable; indicated hospitalization, although death is not imminent); 40 points (unable; need of special care and assistance); 50 points (need of substantial assistance and frequent medical care); 60 points (need of occasional assistance but still able to provide most of your activities in need of active support treatment); 70 points (able to take care of oneself; unable to carry out normal activities or perform active work); 80 points (some signs or symptoms of disease with effort); 90 points (capable of normal activities, small signs and symptoms); 100 points (normal; no complaint or evidence of illness) ${ }^{6}$. 
The ECOG scale was developed by the Eastern Cooperative Oncology Group (ECOG), now part of the ECOG-ACRIN Cancer Research Group, and published in $1982^{7}$. It describes the level of functionality of a patient in terms of ability to care of oneself and physical ability to perform daily activities (walking, working, etc.) and measured in 5 categories: 0 (fully active, capable of performing all of the activities without restriction); 1 (restriction to strict physical activities, capable of light work and sedentary nature, restricted to the bed only in the nocturnal periods of sleep); 2 (able to perform all self-care but unable to perform any work activity; confined to the bed or chair less than $50 \%$ of the hours the patient is awake); 3 (able to perform only limited self-care, confined to the bed or chair more than $50 \%$ of the hours the patient is awake); 4 (completely unable to perform basic self-care, completely confined to the bed or chair).

The nutritional deficit is commonly evaluated by the Body Mass Index (BMI). This index is obtained by the product of weight division by squared height of a person and it is used by the World Health Organization to classify individuals in $\mathrm{BMI}<18.5 \mathrm{~kg} / \mathrm{m}^{2}$ - underweight; $\mathrm{BMI} \geq 18.5$ up to $24.9 \mathrm{~kg} / \mathrm{m}^{2}$ - normal weight; $\mathrm{BMI} \geq 25.0$ to $29.9 \mathrm{~kg} / \mathrm{m}^{2}$ - overweight; $\mathrm{BMI} \geq 30$ up to $34.9 \mathrm{~kg} / \mathrm{m}^{2}$ - class I obesity; BMI $\geq 35.0$ up to $39.9 \mathrm{~kg} / \mathrm{m}^{2}$ - class II obesity; $\mathrm{BMI} \geq 40 \mathrm{~kg} / \mathrm{m}^{2}$ - class III obesity.

The primary outcome of the study was to identify risk factors for postoperative complications by the thirtieth day after the procedure. For this, the complications were first classified in a binary way, that is, complications of any nature, clinical or surgical. Complications were categorized into major and minor complications. Larger complications were those requiring reoperation in a surgical center and under anesthesia. Minor complications were those treated conservatively, that is, without the need for further repair surgery. Conservative treatment comprised dressings, small drains or debridement, and medication use ${ }^{8}$. When one complication led to another, only the latter was considered in an attempt to represent the actual outcome in an individual patient. For example, if a dehiscence resulted in an orocutaneous fistula, then the fistula was ultimately considered as the complication. Ischemic complications, such as partial or total loss of the flap were analyzed separately, independently of the other complications associated with the ischemic event. For example, if a partial loss led to dehiscence and fistula, then they considered "partial loss" and "fistula".

\section{Statistical analysis}

The values obtained by the study of each quantitative variable of parametric distribution were organized and described through the mean, standard deviation, minimum and maximum. For the qualitative variable, absolute and relative frequencies were used. Frequency comparisons were performed using Fisher's exact test. Variables with $p<0.10$ were selected for multivariate analysis using the logistic regression model with hazard ratio (HR) and 95\% confidence intervals (CI 95\%). In all analyses, the statistical program SPSS ${ }^{\circledR}$ version 17.0 (SPSS ${ }^{\circledR}$ Inc; llinois, USA) was used and in all comparisons a level of statistical significance was adopted below $5 \%(p \leq 0.05)$. 


\section{Results}

The sample consisted of 43 patients, between the sixth and seventh decades of life, predominantly male. The most frequent subsets of the primary lesions were oral tongue and floor of the mouth (69.7\%), with advanced stages being the most incident (pT3 or pT4a with lymph node metastasis). The complete descriptive data are described in Table 1.

Table 1. Descriptive data of patients included in the study.

\begin{tabular}{|c|c|}
\hline VARIABLES & RESULT \\
\hline \multicolumn{2}{|l|}{ DEMOGRAPHIC DATA } \\
\hline Male & $33(76.7 \%)$ \\
\hline Age (years) & $60.4 \pm 11.5(31-87)$ \\
\hline \multicolumn{2}{|l|}{ Primary site } \\
\hline Oral tongue & $17(39.5 \%)$ \\
\hline Floor of the mouth & $13(30.2 \%)$ \\
\hline Buccal mucosa & $6(14 \%)$ \\
\hline Lower alveolar ridge & $4(9.3 \%)$ \\
\hline Retromolar area & $2(4.7 \%)$ \\
\hline Hard palate & $1(2.3 \%)$ \\
\hline Smoking & $32(74.4 \%)$ \\
\hline Etilism & $23(53.5 \%)$ \\
\hline \multicolumn{2}{|l|}{ ANATOMY-PATHOLOGICAL DATA } \\
\hline Free resection margins & $34(79.1 \%)$ \\
\hline \multicolumn{2}{|l|}{ Degree of differentiation } \\
\hline Well differentiated & $13(30.2 \%)$ \\
\hline Moderately differentiated & $20(46.5 \%)$ \\
\hline Poorly differentiated & $10(23.3 \%)$ \\
\hline Perineural invasion & $21(48.8 \%)$ \\
\hline Angiolymphatic invasion & $11(25.6 \%)$ \\
\hline \multicolumn{2}{|l|}{ pT } \\
\hline pT1 & $7(16.3 \%)$ \\
\hline pT2 & $7(16.3 \%)$ \\
\hline pT3 & $15(34.9 \%)$ \\
\hline pT4a & $14(32.6 \%)$ \\
\hline \multicolumn{2}{|l|}{$\mathrm{pN}$} \\
\hline pNO & $18(41.9 \%)$ \\
\hline pN1 & $7(16.3 \%)$ \\
\hline $\mathrm{pN} 2 \mathrm{a}$ & $1(2.3 \%)$ \\
\hline $\mathrm{pN} 2 \mathrm{~b}$ & $4(9.3 \%)$ \\
\hline $\mathrm{pN} 2 \mathrm{c}$ & $3(7.0 \%)$ \\
\hline $\mathrm{pN} 3 \mathrm{~b}$ & $10(23.3 \%)$ \\
\hline Tumor size & $38.1 \pm 22.6(4-90) \mathrm{mm}$ \\
\hline Tumor thickness* & $20.1 \pm 14.6(1-60) \mathrm{mm}$ \\
\hline Tumor thickness $>10 \mathrm{~mm}(\mathrm{n}=39)$ & $26(60.5 \%)$ \\
\hline Extracapsular spread $(n=25)$ & $12(48.0 \%)$ \\
\hline
\end{tabular}


The modified Glasgow prognostic score (mGPS) was the predominance of individuals with scores 1 (CRP> $10 \mathrm{mg} / \mathrm{dL}$ ) or 2 (CRP> $10 \mathrm{mg} / \mathrm{dL}$ and albumin $<3.5 \mathrm{mg} / \mathrm{dL}$ ) in $53.5 \%$ of cases. There was also a predominance of patients with good performance status and eutrophic. Moreover, most of the patients required myocutaneous flap for reconstruction of the surgical defect. Seventeen patients presented postoperative complications up to the thirtieth day of follow-up, and $17.6 \%$ of them required surgical reoperation. The most common complications were suture dehiscence and surgical site infections. The full description of the prognostic factors and postoperative complications are detailed in Table 2.

Table 2. Prognostic factors and postoperative complications.

\begin{tabular}{|c|c|}
\hline VARIABLES & RESULT \\
\hline \multicolumn{2}{|l|}{ PROGNOSTIC FACTORS } \\
\hline \multicolumn{2}{|l|}{ Glasgow Prognostic Score Modified (mGPS) } \\
\hline Score 0 (CRP $\leq 10 \mathrm{mg} / \mathrm{dL}$ and albumin $\geq 3.5 \mathrm{mg} / \mathrm{dL})$ & $20(46.5 \%)$ \\
\hline Score 1 (CRP> 10mg/dL) & $19(44.2 \%)$ \\
\hline Score 2 (CRP > 10mg/dL and albumin < 3.5mg/dL) & $4(9.3 \%)$ \\
\hline \multicolumn{2}{|l|}{ ECOG } \\
\hline 0 & $7(16.3 \%)$ \\
\hline 1 & $32(74.4 \%)$ \\
\hline 2 & $3(7.0 \%)$ \\
\hline 3 & $1(2.3 \%)$ \\
\hline \multicolumn{2}{|l|}{ KPS } \\
\hline 50 & $1(2.3 \%)$ \\
\hline 70 & $2(4.7 \%)$ \\
\hline 80 & $18(41.9 \%)$ \\
\hline 90 & $19(44.2 \%)$ \\
\hline 100 & $3(7.0 \%)$ \\
\hline Body Mass Index (BMI)* & $26.0 \pm 7.5(16.8-53.1) \mathrm{kg} / \mathrm{m}^{2}$ \\
\hline Body Mass Index <19.5 kg / m² & $4(9.3 \%)$ \\
\hline Reconstruction with flap & $24(55.8 \%)$ \\
\hline Free flap & $13(30.2 \%)$ \\
\hline Pediculated flap & $11(25.6 \%)$ \\
\hline \multicolumn{2}{|l|}{ POSTOPERATIVE COMPLICATIONS } \\
\hline General complication & $17(39.5 \%)$ \\
\hline Major complications & $3(7.0 \%)$ \\
\hline Minor complications & $9(20.9 \%)$ \\
\hline \multicolumn{2}{|l|}{ Description of complications: } \\
\hline Suture dehiscence & $6(35.3 \%)$ \\
\hline Surgical site infection & $4(23.5 \%)$ \\
\hline Orocutaneous fistula & $3(17.6 \%)$ \\
\hline Cervical hematoma & $3(17.6 \%)$ \\
\hline Partial flap loss & $2(11.8 \%)$ \\
\hline Pneumonia & $1(5.9 \%)$ \\
\hline Venous thrombosis & $1(5.9 \%)$ \\
\hline
\end{tabular}


Alcohol abuse $(p=0.044)$, pT4a tumors $(p=0.044)$, tumors with thickness greater than $10 \mathrm{~mm}(p=0.002)$, patients with mGPS scores 1 and $2(p=0.027)$ and flap reconstruction $(p<0.05)$ 0.001) were associated with higher rates of postoperative complications in patients submitted to surgical treatment for squamous cell carcinoma of the oral cavity (Fisher's exact test) - Table 3.

To the multivariate analysis, patients with tumor thickness greater than $10 \mathrm{~mm}$ (HR=11,240, 95\% Cl: 1,052-120,059, $\mathrm{p}=0.045$ - logistic regression) and reconstructed with myocutaneous flap ( $\mathrm{HR}=18,415,95 \% \mathrm{Cl}: 1,849-183,359$, $p=0.013$ - logistic regression) had a higher risk of developing postoperative complications - Table 4.

Table 3. Analysis of factors related to the development of complications.

\begin{tabular}{|c|c|c|c|}
\hline \multicolumn{2}{|c|}{ VARIABLE } & $\begin{array}{l}\text { COMPLICATION } \\
\text { RATE }\end{array}$ & $\begin{array}{c}\text { p-value } \\
\text { (Fisher exact) }\end{array}$ \\
\hline Smoking & $\begin{array}{l}\text { No } \\
\text { Yes }\end{array}$ & $\begin{array}{r}2 / 11(18.2 \%) \\
15 / 32(46.9 \%)\end{array}$ & 0.154 \\
\hline Alcohol abuse & $\begin{array}{l}\text { No } \\
\text { Yes }\end{array}$ & $\begin{array}{r}3 / 20(15.0 \%) \\
14 / 23(60.9 \%)\end{array}$ & 0.004 \\
\hline Margins & $\begin{array}{c}\text { Free } \\
\text { Positive }\end{array}$ & $\begin{array}{r}13 / 34(38.2 \%) \\
4 / 9(44.4 \%)\end{array}$ & 1.000 \\
\hline $\mathrm{pT}$ & $\begin{array}{c}\text { pT1, pT2, pT3 } \\
\text { pT4a }\end{array}$ & $\begin{array}{l}8 / 29(27.6 \%) \\
9 / 14(64.3 \%) \\
\end{array}$ & 0.044 \\
\hline Tumor thickness & $\begin{array}{l}\leq 10 \mathrm{~mm} \\
>10 \mathrm{~mm}\end{array}$ & $\begin{array}{c}1 / 13(7.7 \%) \\
16 / 26(61.5 \%)\end{array}$ & 0.002 \\
\hline $\mathrm{pN}$ & $\begin{array}{l}\mathrm{pNO} \\
\mathrm{pN}+\end{array}$ & $\begin{array}{r}5 / 18(27.8 \%) \\
12 / 25(28.0 \%)\end{array}$ & 0.219 \\
\hline mGPS & $\begin{array}{l}\text { Score } 0 \\
\text { Score } 1 \\
\text { Score } 2\end{array}$ & $\begin{array}{r}4 / 20(20.0 \%) \\
12 / 19(63.2 \%) \\
1 / 4(25.0 \%) \\
\end{array}$ & 0.027 \\
\hline ECOG & $\begin{array}{l}0 / 1 \\
2 / 3\end{array}$ & $\begin{array}{c}17 / 39(43.6 \%) \\
0 / 4(0.0 \%)\end{array}$ & 0.140 \\
\hline KPS & $\begin{array}{l}>70 \\
\leq 70\end{array}$ & $\begin{array}{c}17 / 40(42.5 \%) \\
0 / 3(0.0 \%)\end{array}$ & 0.266 \\
\hline BMI & $\begin{array}{l}\geq 18.5 \mathrm{~kg} / \mathrm{m}^{2} \\
<18.5 \mathrm{~kg} / \mathrm{m}^{2}\end{array}$ & $\begin{array}{r}14 / 39(35.9 \%) \\
3 / 4(75.0 \%)\end{array}$ & 0.284 \\
\hline Reconstruction with flap & $\begin{array}{l}\text { No } \\
\text { Yes }\end{array}$ & $\begin{array}{c}1 / 19(5.3 \%) \\
16 / 24(66.7 \%)\end{array}$ & $<0.001$ \\
\hline
\end{tabular}

Table 4. Multivariate analysis of factors determining postoperative complications.

\begin{tabular}{lcll}
\multicolumn{1}{c}{ VARIABLE } & \multicolumn{1}{c}{ HR } & \multicolumn{1}{c}{ Cl95\% } & \multicolumn{1}{c}{$\mathbf{p}^{*}$} \\
\hline Alcohol abuse & 6.448 & $0.941-44.200$ & 0.058 \\
\hline pT4a & 0.309 & $0.029-3.333$ & 0.333 \\
\hline Thickness> 10 mm & $\mathbf{1 1 . 2 4 0}$ & $\mathbf{1 . 0 5 2 - 1 2 0 . 0 5 9}$ & $\mathbf{0 . 0 4 5}$ \\
\hline mGPS scores 1 and 2 & 1.603 & $0.206-12.476$ & 0.652 \\
\hline $\begin{array}{l}\text { Reconstruction with } \\
\text { flap }\end{array}$ & $\mathbf{1 8 . 4 1 5}$ & $\mathbf{1 . 8 4 9 - 1 8 3 . 3 5 9}$ & $\mathbf{0 . 0 1 3}$ \\
*Logistic regression. & & &
\end{tabular}




\section{Discussion}

This study evaluated the influence of clinical, pathological and prognostic factors on complications up to the $30^{\text {th }}$ postoperative day in patients with squamous cell carcinoma of the oral cavity. It was identified that tumor thickness greater than $10 \mathrm{~mm}$ and the use of myocutaneous flap in the reconstruction were independent risk factors for postoperative complications.

For decades, the tumor thickness was associated with a worse prognosis, with lower survival and higher rates of treatment failure. When this value is equal or greater than $5 \mathrm{~mm}$, the risk for cervical metastasis is higher and it is considered a "discerning point". Invasive depth greater than $10 \mathrm{~mm}$ is considered as deeply invasive cancer, which led to the American Joint Committee on Cancer (AJCC) incorporating depth of invasion as one of the criteria to be evaluated in the T classification of the new TNM ${ }^{9,10,11}$. In this study, for the first time in the literature, a positive relationship between thickness greater than $10 \mathrm{~mm}$ and a greater chance of postoperative complications was identified. Possibly, thicker tumors require larger resections and, therefore, they are associated with higher rates of complications.

It was also identified that $55.8 \%$ of the patients requiring myocutaneous flap (pedicled or microsurgical) presented postoperative complications, as corroborated by the literature. In these patients, complication rates range from 13 to $65 \%{ }^{12}$. Furthermore, the literature is not consensual about the definition of complications, and there is a wide variety of scenarios, which contributes to such a high dispersion.

Operative wound dehiscence is a common complication in head and neck surgeries, especially in patients who underwent radiation and reconstruction with flap ${ }^{13}$. In our analysis, $17.6 \%$ of the patients required reoperation and six of these patients (35.3\%) were due to suture dehiscence. When the reconstruction of the oral cavity with myocutaneous flap is performed, the most feared complication is the orocutaneous or pharyngocutaneous fistula, present in about 10.7 to $40 \%$ of the cases ${ }^{12}$. In this study, there was a fistula rate of $17.6 \%$, regardless of the type of flap used, and only one case required reoperation.

In the case of microsurgical reconstruction, the main complications that required revision of the vascular anastomosis occurred in about $16.2 \%{ }^{14}$, against $5.9 \%$ in our series. According to this author, total dehiscence of the flap occurred in $4.9 \%$ of the cases, with $95.1 \%$ of the flap survival after sugical revision. Likewise, patients with these complications appear to have reduced survival (specific survival of approximately $60 \%$ at 5 years for stages III and IV) ${ }^{14}$.

Patient-related factors such as nutritional status, performance status, and level of systemic inflammatory response are associated with the prognosis of patients with head and neck cancer ${ }^{6,7}$. Functional status assessments are often employed to complement medical information and characterize the impact of the disease on the patient. Loss of function is usually related to the cumulative physical, physiological, and psychological effects of the disease process ${ }^{6,7}$. In cancer therapy clinical trials, performance status has been shown to be an important predictor of response to therapy and survival ${ }^{4}$. 
In this study, alcohol abuse and elevated mGPS scores were associated with postoperative complications.

Patients who do not interrupt the use of alcoholic behavior tend to have more complications associated with the therapy and an increase in the risk of multiple primary tumors ${ }^{2}$. In this study, also corroborating what is found in the literature, we find that alcoholism as an associated factor to postoperative complications.

In the mGPS analysis, individuals with scores 1 (CRP> $10 \mathrm{mg} / \mathrm{dL}$ ) and 2 (CRP> $10 \mathrm{mg} / \mathrm{dL}$ and albumin $<3.5 \mathrm{mg} / \mathrm{dL}$ ) were predominant. mGPS is considered an independent prognostic factor for cancer patients and its use has already been reported for patients with operable disease, patients undergoing chemotherapy/radiotherapy, and for inoperable cases. An association of 15 studies with more than 2,000 patients demonstrated that high mGPS scores are associated with greater weight loss, poor performance status, increased comorbidities, and treatment complications ${ }^{5}$. Our study corroborates data found in the literature, with high rates of postoperative complications in these patients.

The main virtue of this study was the prospective model, but the limitation was the reduced sample. Thus, the study continues with the inclusion of new patients.

\section{Conclusion}

Tumor thickness greater than $10 \mathrm{~mm}$ or use of myocutaneous flaps in the reconstruction were the predictive factors of risk of postoperative complications in patients with squamous cell carcinoma of the oral cavity.

\section{References}

1. Kolokythas A. Long-term surgical complications in the oral cancer patient: a comprehensive review. Part I. J Oral Maxillofac Res. 2010;1(3):e2. PMid:24421972.

2. Shah JP, Gil Z. Current concepts in management of oral cancer: surgery. Oral Oncol. 2009;45(4-5):394-401. http://dx.doi.org/10.1016/j.oraloncology.2008.05.017. PMid:18674952.

3. Amin MB, Edge S, Greene F, Byrd DR, Brookland RK, Washington MK, Gershenwald JE, Compton CC, Hess KR, Sullivan DC, Jessup JM, Brierley JD, Gaspar LE, Schilsky RL, Balch CM, Winchester DP, Asare EA, Madera M, Gress DM, Meyer LR. AJCC cancer staging manual. 8th ed. Chicago: Springer; 2017. http://dx.doi. org/10.1007/978-3-319-40618-3.

4. McMillan DC. An inflammation-based prognostic score and its role in the nutritionbased management of patients with cancer. Proc Nutr Soc. 2008;67(3):257-62. http://dx.doi.org/10.1017/S0029665108007131. PMid:18452641.

5. McMillan DC. The systemic inflammation-based Glasgow Prognostic Score: a decade of experience in patients with cancer. Cancer Treat Rev. 2013;39(5):53440. http://dx.doi.org/10.1016/j.ctrv.2012.08.003. PMid:22995477. 


\section{*Correspondence}

Leandro Luongo de Matos

Universidade de São Paulo (USP),

Faculdade de Medicina

Av. Dr. Eneas de Carvalho Aguiar, 255,

$8^{\circ}$ andar, sala 8174

CEP 05403-000, São Paulo (SP), Brasil

Tel.: +55 (11) 3069-6425 / Fax: +55 (11)

3069-7506

E-mail: I.matos@fm.usp.br

\section{Authors information}

PVSG - Resident, Hospital das

Clínicas, Faculdade de Medicina, Universidade de São Paulo (USP). DAR - Resident, Hospital das Clínicas, Faculdade de Medicina, Universidade de São Paulo (USP). MAVK - Full Professor, Instituto do Câncer do Estado de São Paulo (ICESP), Faculdade de Medicina, Universidade de São Paulo (USP). CRC - Associate Professor, Hospital das Clínicas, Faculdade de Medicina, Universidade de São Paulo (USP). LLM - Full Professor, Instituto do Câncer do Estado de São Paulo (ICESP), Faculdade de Medicina, Universidade de São Paulo (USP).
6. Karnofsky DA, Abelmann WH, Craver LF, Burchenal JH. The use of the nitrogen mustards in the palliative treatment of carcinoma. Cancer. 1948;1(4):634-56. http://dx.doi. org/10.1002/1097-0142(194811)1:4<634::AID-CNCR2820010410>3.0.CO;2-L.

7. Oken MM, Creech RH, Tormey DC, Horton J, Davis TE, McFadden ET, Carbone PP. Toxicity and response criteria of the Eastern Cooperative Oncology Group. Am J Clin Oncol. 1982;5(6):649-55. http://dx.doi.org/10.1097/00000421-19821200000014. PMid:7165009.

8. Chepeha DB, Annich G, Pynnonen MA, Beck J, Wolf GT, Teknos TN, Bradford CR, Carroll WR, Esclamado RM. Pectoralis major myocutaneous flap vs revascularized free tissue transfer: complications, gastrostomy tube dependence, and hospitalization. Arch Otolaryngol Head Neck Surg. 2004;130(2):181-6. http:// dx.doi.org/10.1001/archotol.130.2.181. PMid:14967747.

9. Spiro RH, Huvos AG, Wong GY, Spiro JD, Gnecco CA, Strong EW. Predictive value of tumor thickness in squamous carcinoma confined to the tongue and floor of the mouth. Am J Surg. 1986;152(4):345-50. http://dx.doi.org/10.1016/00029610(86)90302-8. PMid:3766861.

10. Fukano H, Matsuura H, Hasegawa $\mathrm{Y}$, Nakamura S. Depth of invasion as a predictive factor for cervical lymph node metastasis in tongue carcinoma. Head Neck. 1997;19(3):205-10. http://dx.doi.org/10.1002/(SICI)10970347(199705)19:3<205::AID-HED7>3.0.CO;2-6. PMid:9142520.

11. Shim SJ, Cha J, Koom WS, Kim GE, Lee CG, Choi EC, Keum KC. Clinical outcomes for T1-2N0-1 oral tongue cancer patients underwent surgery with and without postoperative radiotherapy. Radiat Oncol. 2010;5(1):43. http://dx.doi. org/10.1186/1748-717X-5-43. PMid:20504371.

12. Pinto FR, Malena CR, Vanni CM, Capelli FA, Matos LL, Kanda JL. Pectoralis major myocutaneous flaps for head and neck reconstruction: factors influencing occurrences of complications and the final outcome. Sao Paulo Med J. 2010;128(6):336-41. http://dx.doi.org/10.1590/S1516-31802010000600005. PMid:21308156.

13. Arosarena OA. Perioperative management of the head and neck cancer patient. J Oral Maxillofac Surg. 2007;65(2):305-13. http://dx.doi.org/10.1016/j. joms.2005.10.067. PMid:17236939.

14. Chen Y-W, Chen C-Y, Chiang S-C, Lui M-T, Kao S-Y, Yang M-H. Predictors and impact of microsurgical complications in patients with locally advanced oral squamous cell carcinoma. Cancer Sci. 2012;103(9):1672-8. http://dx.doi.org/10.1111/j.13497006.2012.02345.x. PMid:22632121. 